\title{
Pierre-Gilles de GENNES
}

A Life in Science 
This page intentionally left blank 


\title{
Pierre-Gilles de GENNES \\ A Life in Science
}

\section{Laurence Plévert}

\author{
Science Journalist, France
}

\section{Noworld Scientific}


Published by

World Scientific Publishing Co. Pte. Ltd.

5 Toh Tuck Link, Singapore 596224

USA office: 27 Warren Street, Suite 401-402, Hackensack, NJ 07601

UK office: 57 Shelton Street, Covent Garden, London WC2H 9HE

\section{British Library Cataloguing-in-Publication Data}

A catalogue record for this book is available from the British Library.

Cover photo: () Marian Schmidt/Rapho/Eyedea

Interior photos: private collection except p. VII middle and bottom (C) Philippe Nozières. P.X $\odot$ Anne-Marie de Gennes. P. XI, XII and XIII top @ Françoise Brochard-W art. P. XIII bottom @ Henry Thurel. P. XIV bottom $\odot$ Francis Apesteguy/Gam a/Eyedea. P. XV top $\odot$ Thierry Boccon Gibod/ Sipa Press P. XVI bottom (C) Marc Fermier.

Despite our efforts, we have been unable to find the authors of some of the interior photographs. The authors of these photographs are requested to contact Éditions Belin.

\section{PIERRE-GILLES DE GENNES}

A Life in Science

Copyright (c) 2011 by World Scientific Publishing Co. Pte. Ltd.

All rights reserved. This book, or parts thereof, may not be reproduced in any form or by any means, electronic or mechanical, including photocopying, recording or any information storage and retrieval system now known or to be invented, without written permission from the Publisher.

For photocopying of material in this volume, please pay a copying fee through the Copyright Clearance Center, Inc., 222 Rosewood Drive, Danvers, MA 01923, USA. In this case permission to photocopy is not required from the publisher.

ISBN-13 978-981-4355-25-4 (pbk)

ISBN-10 981-4355-25-9 (pbk)

Typeset by Stallion Press

Email: enquiries@stallionpress.com

Printed in Singapore. 


\section{Contents}

Foreword vii

Acknowledgements $\quad$ xi

CHAPTER 1 Childhood Wanderings 1

CHAPTER 2 Birth of a Vocation 21

CHAPTER 3 Studious Years 35

CHAPTER 4 Budding Physicist 43

CHAPTER 5 Research Apprentice 71

$\begin{array}{lll}\text { CHAPTER } 6 & \text { The Big League } & 91\end{array}$

$\begin{array}{lll}\text { CHAPTER } 7 & \text { Team Leader } & 105\end{array}$

CHAPTER 8 The Liquid Crystals Adventure 133

$\begin{array}{lll}\text { CHAPTER } 9 & \text { Out of the Tunnel } & 149\end{array}$

$\begin{array}{lll}\text { CHAPTER } 10 & \text { Recognition } & 159\end{array}$

CHAPTER 11 The Invention of Soft Matter 187

CHAPTER 12 School Director 211

CHAPTER 13 A Different Kind of Nobel 231

CHAPTER 14 Life Goes On 263

CHAPTER 15 “God Willing” 277

CHAPTER 16 France's Pays Tribute 301

$\begin{array}{ll}\text { Appendices } & 319\end{array}$

Bibliography 335

$\begin{array}{ll}\text { Index } & 337\end{array}$ 
This page intentionally left blank 


\section{Foreword}

Over the years, many an editor hit a brick wall in an attempt to persuade Pierre-Gilles de Gennes to write his memoirs: he was not remotely interested in producing an autobiography. He would rather "experience things than talk about them". Nonetheless, in 2005 he accepted my proposal to write his biography, "on condition that it talks about the science!" He formulated this requirement reflecting the meaning of his life, a life marked by his passion for physics.

He made the effort to interrupt his research — which he was pursuing as unflaggingly as ever - for long enough to talk about his memories in the course of some 20 interviews, which he carefully prepared. They were based on the notebooks he had been keeping since the 1960s, jotting down a word or two on his ideas, sometimes with a date and a colleague's name (he was not one of those scientists who kept meticulous "lab notes" on the progress of their work). He intended to use them to reconstruct the sequence of certain ideas, or perhaps to jog his memory, but he had always put off the moment, too absorbed in his current research. Do they contain any potential scientific gems? Whether they do or not, there is enough there to give the historian of science food for thought. Pierre-Gilles de Gennes also unearthed old diaries to retrace the thread of his appointments and travels, year by year. And finally, to make sure that "it talks about the science", he provided comments on his list of publications, pencilling a grey cross besides the ones "worth" mentioning - about one in ten - and highlighting mistakes more often than successes. He could accurately recall articles published 40 or 50 years earlier, in just a few cases wondering: "what exactly was I on about here?". He would sometimes punctuate his explanations, almost apologetically, with "it's a bit abstract”. He also gave me access to his correspondence, kept at ESPCI (Paris Higher School of Industrial Physics and Chemistry), where he 
was the director for 26 years. When I worried that these interviews were taking up too much of his time, his secretary, Marie-Françoise, reassured me that he seemed to enjoy going back over all these memories.

But how can a book recreate the reality of a man as protean as Pierre-Gilles de Gennes? Everyone who met him was struck by his charisma, which is impossible to convey in words. He also radiated enormous kindness, as well as a distinction paradoxically allied with great simplicity, especially in his language: when stuck on some difficult problem, he wouldn't concentrate, but "worry away at it" or "chew it over". To shorten a demonstration, he would sum it up with a "hup-hup" and finish with "or something like that..." to take the edge off his words. But the most striking thing in his way of speaking was undoubtedly that "we", which, while it might be collective at the beginning of the story, could become individual from one sentence to the next, leading his interlocutor to wonder: "so who else is he talking about?", before realising that in fact there was no one else. That was the intention: it wasn't a "royal we", but a "we" of modesty, making him just one of many.

Why dedicate a biography to Pierre-Gilles de Gennes? Other scientists certainly contributed as much as him to 20th century physics, but not all revitalised the subject with such panache; not all had his iconoclastic personality; and, perhaps unjustly, not all were awarded, as he was, the Nobel Prize, that incredible magic wand that brings a physicist into the public eye and which, within a few months, turned Pierre-Gilles de Gennes into a media icon. It was when he entered the courtyard of the Collège de France to find it swarming with journalists and TV trucks on the day of the announcement of the prize, that he realised that it would transform his life.

Amidst the avalanche of mail he received at the time, one particularly amused him: "I'm not surprised that you have won the Nobel Prize, because I heard your mother talking to mine... before you were even born", wrote a childhood girlfriend. A joke? Of course, but his mother was so convinced of her son's genius that she sometimes introduced herself with the words: "Hello, I am the mother of the future Nobel Prize winner Pierre-Gilles de Gennes." He grew up on the pedestal she constructed for him by constantly telling him he was the best. It 
is true that he showed unusual gifts, but intellectual talent is not enough to explain a scientist's success. Pierre-Gilles de Gennes had other qualities that led him not only to revitalise physics, but also to introduce a modern way of reasoning by manipulating orders of magnitude and variables to simplify problems. Throughout his life, he set himself challenges, taking on new subjects — even at the age of 70 - every time he felt himself to be in a scientific rut, preferring demanding labour and the satisfactions of knowledge to the comforts of established success.

Neither historical nor sociological, this book has the modest ambition of revealing something of the great physicist and something of the human being (in particular, he was kind enough to lift part of the veil over his private life by passing on personal memories). For it is above all the man he was that made him "France's favourite physicist", a man whose freedom of thought is missed more with each day that passes. As far as possible, this book tells the story in Pierre-Gilles de Gennes' own words, but there is no way that it can convey the power of his presence. Although the text follows the interviews as closely as possible, it also owes its existence to those who accepted, always with great pleasure, to talk about the times spent in his company. I am extremely grateful to each of them for sharing some of their memories: their insights or testimonies have made this biography possible, like a photograph put together from scattered fragments. Some fragments are missing, some are perhaps in the wrong place, and the odd piece of sticky tape is visible, but at least it's there.

Pierre-Gilles de Gennes always stressed how much the American physicist Richard Feynman had inspired him: "For me, brought up in the French way with a mindless respect for formalism, the game changer was the Feynman Lectures on Physics (...): for our generation, the message of that book, its critique, its outbursts, were a sort of Road to Damascus experience", he wrote in $1990 .{ }^{1}$ Let us hope that he too will become a guide for future generations.

\footnotetext{
${ }^{1}$ Martine Poulain, La bibliothèque imaginaire du Collège de France, Le Monde éditions, 1990.
} 
This page intentionally left blank 


\section{Acknowledgements}

This book would not have been possible without the personal contributions of Anatole Abragam, Mireille Adam, Armand Ajdari, Claude Allègre, Vinay Ambegaokar, André Authier, Pierre Averbuch, Jacques Badoz, Sébastien Balibar, Jean-Pierre Beaufils, Henri Benoît, Jean-Claude Bizot, Julien Bok, Bernard Bourgeois, Thomas Boutreux, Édouard Brézin, Françoise Brochard-Wyart, Dominique Bomm, Christiane Caroli, Jacques Chemin, Jean-Pierre Chevènement, Daniel Cribier, Mohammed Daoud, Guy Deutscher, Anne-Marie de Gennes, Christian de Gennes, Estrella de Laredo, Élisabeth Dubois-Violette, Jacques Duran, Georges Durand, Jacques Friedel, Jean Gavoret, Sylvain Gilat, Robert Goutte, Marie-Alice Guedeau-Boudeville, Étienne Guyon, Françoise Hartmann-Boutron, Yvette Heffer, Hubert Hervet, Bernard Jacrot, Jean-François Joanny, Jacques Joffrin, Charles Kittel, Michel Laguës, Marie-Françoise Lancastre, Liliane Léger, Jean Léoni, Jacques Lewiner, Alexis Martinet, Jean Matricon, Barry Mazur, Lucien Monnerie, MarieCaroline Müller, Philippe Nozières, Roland Omnès, Marie-Christine Picard de Gennes, Pawel Pieranski, Phil Pincus, Jacques Prost, Bernard Prugnat, David Quéré, Élie Raphaël, André Rassat, Francis Rondelez, Gilles Rubinstenn, Daniel Saint-James, Lisbeth Saraga, Georges Sarre, Bruno Schroeder, Jacques Signoret, Christiane Taupin, André-Marie Tremblay, Gérard Toulouse, Madeleine Veyssié, Jacques Villain and Claire Wyart.

Chapter 6 owes much to Pierre Billaud, who described to me the conditions in Reggane, in the Algerian Sahara, at the time of the first French nuclear explosions (I recommend that you read his account of the early days of the French nuclear deterrent on his website). 
Jacques Friedel closely followed this project and I am deeply grateful to him for his intelligent comments. Françoise BrochardWyart, Guy Deutscher, Jacques Duran, Bernard Jacrot, Lucien Monnerie, Philippe Nozières, Francis Rondelez, Madeleine Veyssié and Jacques Villain gave me invaluable help in the correction of the scientific passages.

Denis Blaizot, Philippe Boulanger, Sébastien Carganico, Claire Guttinger, Pierre Lutz, Fabienne Longeville and Olivier Vaginay also helped me, as did Caroline Burnel, Yvette Firminhac, Viviane Fuchs and Catherine Kounelis from the ESPCI library (Paris Higher School of Industrial Chemistry and Physics), whom I would like to thank for their assistance.

I am also grateful to the scientific department at Éditions Belin, in particular to its manager and the editor of this book, for having supported the project from the start.

Finally, I would like to thank Armand Ajdari, whose 1992 classes on soft matter at the University of Rennes I still remember, and to whom this book owes much. I hope that he will not be offended if I repeat the words of his grandfather, Robert Buron, a minister under the 4th and 5th Republics, which provide such a good summary of what makes a good researcher: "The taste of the fruit that one eats and of the wine that one drinks, the smell of mown grass and the scent of flowers, the sight of the ocean in sunlight or in cloud, the sound of vibrating strings or the crash of waves upon rocks, the almost disconcerting softness of fur, velvet or hide... but even more than those, the sense of excitement that comes from the logical explanation of a problem or phenomenon not previously understood, the discovery of a previously unknown field elucidated by a new insight (...), that is the inimitable and marvellous taste of life." 